\title{
YIELD FORMATION OF WHITE LUPIN LUPINUS ALBUS L. ON HEAVY GLEYEY ALLUVIAL SOIL
}

\author{
DANICA ŠARIKOVÁ, ANDREJ HNÁT, PETER FECÁK
}

Plant Production Research Center Piešt'any

ŠARIKOVÁ, D. - HNÁT, O. - FECÁK, P.: Yield formation of white lupin Lupinus albus L. on heavy gleyey alluvial soil. Agriculture (Pol'nohospodárstvo), vol. 57, 2011, no. 2, pp. 53-60.

Field trial with white lupin Lupinus albus L., an anti-trypsin-free French cultivar Amiga, on heavy gleyey alluvial soil of the research base in Milhostov (alt.: $101 \mathrm{~m}$, avg. year temp.: $9.0^{\circ} \mathrm{C}$, year precip.: $559 \mathrm{~mm}$ ) in the trial years of $2006-2008$ was performed. The influence of three seeding rates: 0.55 , $0.65,0.75$ million viable seeds per ha (MVS) and three doses of $\mathrm{N}$ fertilization: $25,50,75 \mathrm{~kg} \mathrm{ha}^{-1} \mathrm{~N}$ on seed yield and yield components such as plant number per $\mathrm{m}^{2}$, pod number per plant, seed number per plant and thousand seed weight was tested in the trial. The data of randomized complete block design trial were statistically evaluated by ANOVA and LSD method. All tested factors had highly significant $(\mathrm{P} \leq 0.01)$ influence on seed yield. Seed yield was especially influenced by weather in year $(97.8 \%$ influence), followed by seeding rate with the influence of $1.8 \%$ and $\mathrm{N}$ fertilization with the influence of $0.3 \%$ only. The highest seed yield of $2.21 \mathrm{t} \mathrm{ha}^{-1}$ was under the highest seeding rate of 0.75 MVS with the difference of 0.36 t ha ${ }^{-1}(19.5 \%)$ in comparison with the lowest seeding rate of 0.55 MVS $\left(1.85 \mathrm{t} \mathrm{ha}^{-1}\right)$ and about $0.15 \mathrm{t} \mathrm{ha}^{-1}(10.7 \%)$ higher in comparison with the seeding rate of 0.65 MVS $\left(2.06 \mathrm{t} \mathrm{ha}^{-1}\right)$. The highest influence on seed yield had the dose of $75 \mathrm{~kg} \mathrm{ha}^{-1}$ $\mathrm{N}$. The seed yield of $2.09 \mathrm{t} \mathrm{ha}^{-1}$ under the treatment with the highest dose of $75 \mathrm{~kg} \mathrm{ha}^{-1} \mathrm{~N}$ was about $0.13 \mathrm{t} \mathrm{ha}^{-1}(6.6 \%)$ higher than the yield under the treatment with the lowest dose of 25 $\mathrm{kg} \mathrm{ha}^{-1} \mathrm{~N}\left(1.96 \mathrm{t} \mathrm{ha}^{-1}\right)$. All yield components were highly significantly $(\mathrm{P} \leq 0.01)$ influenced by weather in year. Plant number per $\mathrm{m}^{2}$ was also highly significantly $(\mathrm{P} \leq 0.01)$ influenced by all tested factors.

Key words: white lupin, weather, $\mathrm{N}$ fertilization, seeding rate, seed yield, yield components

White lupin Lupinus albus L. is a forage species from the family Fabaceae. It is cultivated in several European countries such as: France, Spain, Poland, Ukraine, Russia, Germany and others. White lupin hectarage in adjacent Czech Republic enlarges greatly at present because of a registered French cultivar Amiga. This cultivar is free of anti-trypsin factors that enable its direct use as a protein component of feed rations without any thermal processing. Other strength of the cultivar is higher seed yield and higher resistance to anthracnose as well as faster initial growth. Growers in Slovakia showed interest in the growing of white lupin not only as a component in feed rations but also as a soil-improving crop in crop rotations in the last few years. Its nutritious value is very similar to that of soy- bean. It is possible to use whole plants as green feed or seed that could substitute soybean meal in feed rations. White lupin seed is valuated for its high protein content (Payne et al. 2004; Raza \& Jørnsgård 2005). Influence of the environmental factors (weather, locality) and cropping system factors (drilling date, seeding rate, row distance, fertilization) on seed yield and yield components in white lupin was tested by the following researchers: Milford et al. (1993), López-Bellido et al. (1994), Shield et al. (1996), Payne et al. (2004), Wiatrak et al. (2004), Raza and Jørnsgård (2005), Ciesiołka et al. (2007), Gonzáles-Andrés et al. (2007). It is imperative to drill white lupin in early spring. Dry conditions slower germination tremendously (Belej 1989). Late drilling decreases seed yield about $10 \%$ per week.

Ing. Danica Šariková, CSc., Ing. Andrej Hnát, Ing. Peter Fecák, PhD., Plant Production Research Center - Institute of Agroecology, 07101 Michalovce, Špitálska 1273, Slovak Republic. E-mail: sarikova@minet.sk; hnat@minet.sk 
Late drilling also prolongs the flowering and maturity growth stages. High temperatures slower plant growth, pod and seed formation with subsequent yield reduction. The quality of drilling has very high influence on plant number per ha and even plant distribution on a field area. Optimum plant number should be in the range of $60-80$ plants per $\mathrm{m}^{2}$. The drier the soil the higher the seeding rate - this rule of thumb should be applied. A seed yield of 1 tonne uptakes $70-80 \mathrm{~kg} \mathrm{~N}$, 9-10 kg P and 37-40 kg K. Even though white lupin can utilize atmospheric nitrogen, fertilization in the dose of $60-80 \mathrm{~kg} \mathrm{ha}^{-1} \mathrm{~N}$ is important for higher seed yield (Belej 1989). Due to the lack of experience with white lupin cultivation in the East Slovak Lowland, it was necessary to test different seeding rates and $\mathrm{N}$ fertilizer doses.

Our research was aimed at rationalization of seeding rate and $\mathrm{N}$ fertilization in the cropping system of white lupin in the specific conditions of heavy gleyey soil of the East Slovak Lowland.

\section{MATERIAL AND METHODS}

Field trial with white lupin, a French cultivar Amiga, was established on gleyey alluvial soil of the research base in Milhostov (alt.: $101 \mathrm{~m}$, avg. year temp.: $9.0^{\circ} \mathrm{C}$, year precip.: $559 \mathrm{~mm}$ ). The gleyey alluvial soil belongs to heavy soils with the amount of clay particles $(<0.01 \mathrm{~mm}$ ) higher than 53\% (Kotorová et al. 2010). Their agronomic properties are negatively influenced by a high content of clay particles. The soil had the following selected chemical properties: soil organic matter $=2.7 \%, \mathrm{pH} / \mathrm{KCl}=6.5$, available $\mathrm{P}=55 \mathrm{mg} \mathrm{kg}^{-1}$, available $\mathrm{K}=140 \mathrm{mg} \mathrm{kg}^{-1}$, available $\mathrm{Mg}=195 \mathrm{mg} \mathrm{kg}^{-1}$. Two-rowed spring barley was a preceding crop for white lupin. The soil was prepared by conventional tillage (stubble cleaning followed by ploughing in the autumn and seedbed preparation by a combined tillage implement in the spring). The influence of three seeding rates: $0.55,0.65,0.75$ million viable seeds per ha (MVS) and three doses of $\mathrm{N}$ fertilization: $25,50,75 \mathrm{~kg} \mathrm{ha}^{-1} \mathrm{~N}$ on seed yield and yield components: plant number per $\mathrm{m}^{2}$, pod number per plant, seed number per plant and thousand seed weight (TSW) were tested in the trial. $\mathrm{N}$ was broadcast before drilling as calcium ammonium nitrate; $30 \mathrm{~kg} \mathrm{ha}^{-1}$ $\mathrm{P}$ and $100 \mathrm{~kg} \mathrm{ha}^{-1} \mathrm{~K}$ was also applied. The doses of $\mathrm{P}$ and $\mathrm{K}$ were calculated on the basis of soil tests and expected yield requirements. White lupin seed was inoculated by Nitrazon containing Rhizobium lupini and seed-dressed by fludioxonil plus mefenoxam. Drilling was done by a plot drill Oyord early in the spring as soon as it was possible to enter the field. Preemergent herbicide application of linuron and S-metolachlor was done to control weeds. The trial was organized as a randomized complete block design with four replications. Single plot has an area of $15 \mathrm{~m}^{2}(10 \times 1.5 \mathrm{~m})$.

$\mathrm{T}$ a b 1 e 1

Average monthly temperatures in ${ }^{\circ} \mathrm{C}$ during the growing seasons of $2006-2008$ in comparison with the long-term average of 1951-1980 (LA)

\begin{tabular}{|l|c|c|c|c|c|c|c|c|c|c|}
\hline Month & LA & 2006 & $\Delta$ LA & Ev. & 2007 & $\Delta$ LA & Ev. & 2008 & $\Delta$ LA & Ev. \\
\hline III. & 3.5 & 2.3 & -1.2 & $\mathrm{~N}$ & 8.2 & 4.7 & EW & 5.1 & 1.6 & $\mathrm{~N}$ \\
IV. & 9.7 & 11.3 & 1.6 & $\mathrm{~W}$ & 11.2 & 1.5 & $\mathrm{~N}$ & 10.7 & 1.0 & $\mathrm{~N}$ \\
V. & 14.6 & 14.8 & 0.2 & $\mathrm{~N}$ & 17.5 & 2.9 & $\mathrm{VW}$ & 15.0 & 0.4 & $\mathrm{~N}$ \\
VI. & 18.2 & 18.8 & 0.6 & $\mathrm{~N}$ & 20.7 & 2.5 & $\mathrm{VW}$ & 19.3 & 1.1 & $\mathrm{~N}$ \\
VII. & 19.6 & 22.5 & 2.9 & $\mathrm{EW}$ & 22.5 & 2.9 & $\mathrm{EW}$ & 19.7 & 0.1 & $\mathrm{~N}$ \\
VIII. & 18.9 & 18.8 & -0.1 & $\mathrm{~N}$ & 21.7 & 2.8 & $\mathrm{EW}$ & 20.1 & 1.2 & $\mathrm{~W}$ \\
IX. & 14.8 & 16.3 & 1.5 & $\mathrm{~W}$ & 13.6 & -1.2 & $\mathrm{C}$ & 14.0 & -0.8 & $\mathrm{~N}$ \\
\hline $\bar{x}$ IV.-IX. & 16.0 & 17.1 & 1.1 & $\mathrm{~W}$ & 17.9 & 1.9 & $\mathrm{VW}$ & 16.5 & 0.5 & $\mathrm{~N}$ \\
\hline $\bar{x}$ I.-XII. & 9.0 & 9.6 & 0.6 & $\mathrm{~W}$ & 11.0 & 2.0 & $\mathrm{EW}$ & 10.2 & 1.2 & $\mathrm{~W}$ \\
\hline
\end{tabular}

$\Delta$ LA - deviation of long-term average, Ev. - evaluation, C - cold, N - normal, W - warm, VW - very warm, EW - extremely warm 
Seed yield was harvested by hand at the stage of full maturity and was expressed on $86 \%$ dry matter basis. The data were evaluated by ANOVA and LSD method by Statgraphics, version 5.0.

\section{RESULTS AND DISCUSSION}

Very essential factor influencing not only plant growth but also seed yield of white lupin is undoubtedly weather in year. The weather conditions of the trial locality in 2006-2008, characterized by temperatures and sums of precipitation, were evaluated according to Kožnarová and Klabzuba (2002) and presented in Table 1 and 2. In terms of a sum of precipitation during a growing season, it can be said that this period in 2006 was pretty wet with the sum of $402 \mathrm{~mm}$ precipitation (116\% of the long-term average of 1951-1980). The wet spring in 2006 delayed drilling. On the contrary, July was very dry with the sum of $18 \mathrm{~mm}$ precipitation only ( $24 \%$ of the long-term average) and this period influenced white lupin growth very negatively. The driest growing season was in 2007 with the sum of $328 \mathrm{~mm}$ precipitation ( $94 \%$ of the long-term aver-

$\mathrm{T}$ a $\mathrm{b} 1$ e 2

Monthly sums of precipitation in mm during the growing seasons of 2006-2008 in comparison with the long-term average of 1951-1980 (LA)

\begin{tabular}{|l|r|r|r|r|r|r|r|r|r|r|}
\hline Month & LA & 2006 & LA [\%] & Ev. & 2007 & LA [\%] & Ev. & 2008 & LA [\%] & Ev. \\
\hline III. & 27 & 48 & 178 & VW & 18 & 67 & $\mathrm{~N}$ & 30 & 111 & $\mathrm{~N}$ \\
IV. & 39 & 49 & 126 & $\mathrm{~N}$ & 6 & 15 & $\mathrm{ED}$ & 48 & 123 & $\mathrm{~N}$ \\
V. & 53 & 83 & 157 & $\mathrm{~W}$ & 38 & 72 & $\mathrm{~N}$ & 40 & 76 & $\mathrm{~N}$ \\
VI. & 78 & 96 & 123 & $\mathrm{~N}$ & 72 & 92 & $\mathrm{~N}$ & 61 & 78 & $\mathrm{~N}$ \\
VII. & 76 & 18 & 24 & $\mathrm{VD}$ & 36 & 47 & $\mathrm{D}$ & 140 & 184 & $\mathrm{VW}$ \\
VIII. & 63 & 151 & 240 & $\mathrm{EW}$ & 29 & 46 & $\mathrm{D}$ & 53 & 84 & $\mathrm{~N}$ \\
IX. & 41 & 5 & 12 & $\mathrm{VD}$ & 147 & 359 & $\mathrm{EW}$ & 34 & 83 & $\mathrm{~N}$ \\
\hline $\bar{x}$ IV.-IX. & 348 & 402 & 116 & $\mathrm{~N}$ & 328 & 94 & $\mathrm{~N}$ & 376 & 108 & $\mathrm{~N}$ \\
\hline $\bar{x}$ I.-XII. & 559 & 556 & 99 & $\mathrm{~N}$ & 543 & 97 & $\mathrm{~N}$ & 554 & 99 & $\mathrm{~N}$ \\
\hline
\end{tabular}

LA [\%] - percentage of long-term average, Ev. - evaluation, ED - extremely dry, VD - very dry, D - dry, N - normal, $\mathrm{W}$ - wet, VW - very wet, EW - extremely wet

$\mathrm{T}$ a $\mathrm{b} 1$ e 3

Dates of selected agronomic operations and growth stages of white lupin

\begin{tabular}{|l|c|c|c|}
\hline \multirow{2}{*}{$\begin{array}{c}\text { Agronomic operation or growth } \\
\text { stage }\end{array}$} & 2006 & 2007 & 2008 \\
\cline { 2 - 4 } & $4^{\text {th }}$ May & $12^{\text {th }}$ March & $31^{\text {st }}$ March \\
\hline Seedbed preparation & $5^{\text {th }}$ May & $16^{\text {th }}$ March & $1^{\text {st }}$ April \\
Drilling & $6^{\text {th }}$ September & $25^{\text {th }}$ July & $6^{\text {th }}$ August \\
Harvest & $18^{\text {th }}$ May & $20^{\text {th }}$ April & $23^{\text {rd }}$ April \\
\hline Beginning emergence & $25^{\text {th }}$ May & $24^{\text {th }}$ April & $28^{\text {th }}$ April \\
Full emergence & $23^{\text {rd }}$ June & $11^{\text {th }}$ May & $16^{\text {th }}$ May \\
Beginning bloom & $8^{\text {th } J u l y ~}$ & $20^{\text {th }}$ May & $4^{\text {th }}$ Jun \\
Full bloom & $22^{\text {nd }}$ August & $15^{\text {th }}$ July & $4^{\text {th }}$ August \\
Full maturity & & \\
\hline
\end{tabular}


$\mathrm{T}$ a b 1 e 4

Seed yield $\left[\mathrm{tha}^{-1}\right]$ as influenced by the treatments

\begin{tabular}{|c|c|c|c|c|c|}
\hline \multirow{2}{*}{$\begin{array}{c}\text { Seeding } \\
\text { rate }\end{array}$} & \multirow{2}{*}{$\begin{array}{c}\mathrm{N} \\
\text { fertilization }\end{array}$} & \multicolumn{3}{|c|}{ Trial year } & \multirow{2}{*}{$\bar{x} \bar{x}$} \\
\hline & & 2006 & 2007 & 2008 & \\
\hline \multirow{3}{*}{$a_{1}$} & $\mathrm{~b}_{1}$ & 1.47 & 0.79 & 3.18 & - \\
\hline & $\mathrm{b}_{2}$ & 1.42 & 0.88 & 3.30 & - \\
\hline & $\mathrm{b}_{3}$ & 1.32 & 0.90 & 3.36 & - \\
\hline \multicolumn{2}{|l|}{$\begin{array}{ll}\bar{x} & \mathrm{a}_{1} \\
\end{array}$} & 1.40 & 0.86 & 3.28 & 1.85 \\
\hline \multirow{3}{*}{$\mathrm{a}_{2}$} & $b_{1}$ & 1.53 & 0.95 & 3.47 & - \\
\hline & $b_{2}$ & 1.61 & 1.06 & 3.64 & - \\
\hline & $b_{3}$ & 1.45 & 1.08 & 3.75 & - \\
\hline \multicolumn{2}{|l|}{$\bar{x} \mathrm{a}_{2}$} & 1.53 & 1.03 & 3.62 & 2.06 \\
\hline \multirow{3}{*}{$a_{3}$} & $b_{1}$ & 1.30 & 1.12 & 3.80 & - \\
\hline & $\mathrm{b}_{2}$ & 1.66 & 1.17 & 3.88 & - \\
\hline & $\mathrm{b}_{3}$ & 1.86 & 1.20 & 3.94 & - \\
\hline \multicolumn{2}{|l|}{$\bar{x} \mathrm{a}_{3}$} & 1.61 & 1.16 & 3.87 & 2.21 \\
\hline \multicolumn{2}{|l|}{$\bar{x} b_{1}$} & 1.43 & 0.95 & 3.48 & 1.96 \\
\hline \multicolumn{2}{|l|}{$\bar{x} \mathrm{~b}_{2}$} & 1.56 & 1.04 & 3.61 & 2.07 \\
\hline \multicolumn{2}{|l|}{$\bar{x} \mathrm{~b}_{3}$} & 1.54 & 1.06 & 3.68 & 2.09 \\
\hline \multicolumn{2}{|l|}{$\bar{x} \bar{x}$} & 1.51 & 1.02 & 3.59 & 2.04 \\
\hline
\end{tabular}

age) and this period was also very warm with the average temperature of $17.9^{\circ} \mathrm{C}\left(1.9^{\circ} \mathrm{C}\right.$ above the long-term average). These conditions affected white lupin plants very negatively. The most suitable weather conditions for white lupin growth was during the growing season in 2008 with the sum of $376 \mathrm{~mm}$ precipitation $(108 \%$ of the long-term average) and the average temperature of $16.5^{\circ} \mathrm{C}\left(0.5^{\circ} \mathrm{C}\right.$ above the long-term average $)$. Different weather conditions during the trial years caused various dates of drilling and harvest (Table 3). Due to unfavourable weather conditions in the spring of 2006, white lupin was drilled as late as on $5^{\text {th }}$ May. Germination and emergence were slow and uneven. Consequently, the plants were very short ( $0.46 \mathrm{~m}$ only) with one floor having pods only. The shortest growing season (110 days) was in 2006. Different situation was in 2007 when drilling was done very early in the spring, on $16^{\text {th }}$ March. Unfortunately, owing to unfavourable weather conditions after drilling - extremely dry, white lupin emerged very slowly and unevenly. Full emergence was completed as late as 39 days after drilling. Besides that, the effect of preemergent herbicide application was very weak, so the stand was very weedy. High average monthly temperatures during April-Au-

$\mathrm{T}$ a $\mathrm{b} 1 \mathrm{e} 5$

Plant number per $\mathrm{m}^{2}$ and pod number per plant as influenced by the treatments

\begin{tabular}{|c|c|c|c|c|c|c|c|c|c|}
\hline \multirow{3}{*}{$\begin{array}{l}\text { Seeding } \\
\text { rate }\end{array}$} & \multirow{3}{*}{$\begin{array}{c}\mathrm{N} \\
\text { fertilization }\end{array}$} & \multicolumn{4}{|c|}{ Plant number per $\mathrm{m}^{2}$ [piece] } & \multicolumn{4}{|c|}{ Pod number per plant [piece] } \\
\hline & & \multicolumn{3}{|c|}{ Trial year } & \multirow{2}{*}{$\bar{x} \bar{x}$} & \multicolumn{3}{|c|}{ Trial year } & \multirow{2}{*}{$\bar{x} \bar{x}$} \\
\hline & & 2006 & 2007 & 2008 & & 2006 & 2007 & 2008 & \\
\hline \multirow{3}{*}{$a_{1}$} & $\mathrm{~b}_{1}$ & 36.5 & 47.8 & 48.0 & - & 4.5 & 2.1 & 6.3 & - \\
\hline & $b_{2}$ & 24.1 & 53.0 & 48.1 & - & 5.4 & 2.0 & 6.9 & - \\
\hline & $b_{3}$ & 26.0 & 41.4 & 51.9 & - & 5.3 & 2.4 & 5.9 & - \\
\hline \multicolumn{2}{|l|}{$\bar{x} \mathrm{a}_{1}$} & 28.9 & 47.4 & 49.3 & 41.9 & 5.1 & 2.2 & 6.4 & 4.53 \\
\hline \multirow{3}{*}{$\mathrm{a}_{2}$} & $\mathrm{~b}_{1}$ & 37.3 & 57.6 & 54.0 & - & 4.8 & 1.9 & 5.8 & - \\
\hline & $b_{2}$ & 33.5 & 46.8 & 54.1 & - & 4.7 & 2.9 & 6.3 & - \\
\hline & $b_{3}$ & 36.1 & 45.9 & 53.2 & - & 5.0 & 2.9 & 7.2 & - \\
\hline \multicolumn{2}{|l|}{$\bar{x} \mathrm{a}_{2}$} & 35.6 & 50.1 & 53.8 & 46.5 & 4.8 & 2.6 & 6.4 & 4.61 \\
\hline \multirow{3}{*}{$a_{3}$} & $b_{1}$ & 38.6 & 57.0 & 61.1 & - & 3.9 & 2.3 & 5.8 & - \\
\hline & $b_{2}$ & 45.7 & 56.1 & 64.0 & - & 4.3 & 3.1 & 6.5 & - \\
\hline & $b_{3}$ & 39.3 & 48.0 & 65.0 & - & 4.8 & 2.7 & 6.6 & - \\
\hline \multicolumn{2}{|l|}{$\bar{x} \mathrm{a}_{3}$} & 41.2 & 53.7 & 63.4 & 52.8 & 4.3 & 2.7 & 6.3 & 4.44 \\
\hline \multicolumn{2}{|l|}{$\bar{x} b_{1}$} & 37.4 & 54.1 & 54.4 & 48.6 & 4.40 & 2.10 & 6.00 & 4.17 \\
\hline \multicolumn{2}{|l|}{$\bar{x} \mathrm{~b}_{2}$} & 34.4 & 52.0 & 55.4 & 47.3 & 4.80 & 2.67 & 6.57 & 4.68 \\
\hline \multicolumn{2}{|l|}{$\bar{x} \mathrm{~b}_{3}$} & 33.8 & 45.1 & 56.7 & 45.2 & 5.03 & 2.67 & 6.57 & 4.75 \\
\hline \multicolumn{2}{|l|}{$\bar{x} \bar{x}$} & 35.2 & 50.4 & 55.5 & 47.0 & 4.74 & 2.48 & 6.37 & 4.53 \\
\hline
\end{tabular}

Seeding rate: $\mathrm{a}_{1}-0.55, \mathrm{a}_{2}-0.65, \mathrm{a}_{3}-0.75$ million viable seeds per ha; $\mathrm{N}$ fertilization: $\mathrm{b}_{1}-25, \mathrm{~b}_{2}-50, \mathrm{~b}_{3}-75 \mathrm{~kg} \mathrm{ha}^{-1} \mathrm{~N}$ 
gust $2007\left(18.7^{\circ} \mathrm{C}, 2.5^{\circ} \mathrm{C}\right.$ above the long-term average) and low precipitation (181 mm, 59\% of long-term average) as well as necessary postemergent herbicide application slower growth and development of white lupin. The plants were very short, about $0.28 \mathrm{~m}$, with the lowest number of pods per plant of all trial years, 2.48 pods only. The growing season in 2007 lasted 122 days. Favourable weather conditions during the growing season in 2008 positively influenced white lupin plants, so the height of the plants was as high as 0.55 $\mathrm{m}$. The growing season in 2008 was the longest and lasted as many as 128 days.

Seed yield in the trial years of 2006-2008 ranged from $0.79 \mathrm{t} \mathrm{ha}^{-1}$ to $3.94 \mathrm{t} \mathrm{ha}^{-1}$, so the range of 3.15 $\mathrm{t} \mathrm{ha} \mathrm{a}^{-1}$ can be marked as quite large (Table 4). The highest seed yield of $3.59 \mathrm{t} \mathrm{ha}^{-1}$ was found in 2008 , about $2.57 \mathrm{tha}^{-1}$ higher in comparison with the lowest yield of $1.02 \mathrm{t} \mathrm{ha}^{-1}$ in 2007. The average seed yield of the whole trial period was $2.04 \mathrm{t} \mathrm{ha}^{-1}$. The highest seed yield of $2.21 \mathrm{tha}^{-1}$ under the treatment with the 0.75 MVS seeding rate was about $0.36 \mathrm{tha}^{-1}(19.5 \%)$ higher in com- parison with the lowest seeding rate of $0.55 \mathrm{MVS}$ and about $0.15 \mathrm{t} \mathrm{ha}^{-1}(11.4 \%)$ with the 0.65 MVS seeding rate. Seed yield was also positively influenced by $\mathrm{N}$ fertilization. The highest seed yield of $2.09 \mathrm{t} \mathrm{ha}^{-1}$ was found under the treatment with $75 \mathrm{~kg} \mathrm{ha}^{-1} \mathrm{~N}$. This yield was about $0.13 \mathrm{t} \mathrm{ha}^{-1}(6.6 \%)$ higher in comparison with the treatment with the lowest dose of $25 \mathrm{~kg} \mathrm{ha}^{-1} \mathrm{~N}(1.96$ $\left.\mathrm{t} \mathrm{ha}^{-1}\right)$. The difference in seed yield between the treatments with $50 \mathrm{~kg} \mathrm{ha}^{-1} \mathrm{~N}\left(2.07 \mathrm{t} \mathrm{ha}^{-1}\right)$ and $75 \mathrm{~kg} \mathrm{ha}^{-1} \mathrm{~N}$ $\left(2.09 \mathrm{t} \mathrm{ha}^{-1}\right)$ was nonsignificant $(\mathrm{P}>0.05)$. Based on $\mathrm{N}$ fertilization, the higher the $\mathrm{N}$ dose the higher the seed yield (Table 4). ANOVA revealed that all tested factors influenced seed yield highly significantly $(\mathrm{P} \leq 0.01)$. The most important factor influenced seed yield was weather in year with $97.8 \%$ influence of all tested factors. Seeding rate and $\mathrm{N}$ fertilization had $1.8 \%$ and $0.3 \%$ influence, respectively (Table 7). These results regarding high influence of year on seed yield based on the trials with some other leguminous crops were confirmed by Šariková and Hnát (2005), Fecák et al. (2009). High seed yield variability caused by a local-

$\mathrm{T}$ a b 1 e 6

Seed number per plant and thousand seed weight as influenced by the treatments

\begin{tabular}{|c|c|c|c|c|c|c|c|c|c|}
\hline \multirow{3}{*}{$\begin{array}{l}\text { Seeding } \\
\text { rate }\end{array}$} & \multirow{3}{*}{$\begin{array}{c}\mathrm{N} \\
\text { fertilization }\end{array}$} & \multicolumn{4}{|c|}{ Seed number per plant [piece] } & \multicolumn{4}{|c|}{ Thousand seed weight [g] } \\
\hline & & \multicolumn{3}{|c|}{ Trial year } & \multirow{2}{*}{$\bar{x} \bar{x}$} & \multicolumn{3}{|c|}{ Trial year } & \multirow{2}{*}{$\bar{x} \bar{x}$} \\
\hline & & 2006 & 2007 & 2008 & & 2006 & 2007 & 2008 & \\
\hline \multirow{3}{*}{$a_{1}$} & $\mathrm{~b}_{1}$ & 14.7 & 5.7 & 20.3 & - & 274 & 290 & 326 & - \\
\hline & $\mathrm{b}_{2}$ & 21.4 & 5.3 & 20.5 & - & 275 & 313 & 328 & - \\
\hline & $\mathrm{b}_{3}$ & 19.6 & 7.5 & 20.6 & - & 259 & 290 & 314 & - \\
\hline \multicolumn{2}{|l|}{$\bar{x} \mathrm{a}_{1}$} & 18.6 & 6.2 & 20.5 & 15.07 & 269.3 & 297.7 & 322.7 & 296.6 \\
\hline \multirow{3}{*}{$a_{2}$} & $\mathrm{~b}_{1}$ & 16.8 & 5.1 & 19.7 & - & 244 & 323 & 326 & - \\
\hline & $b_{2}$ & 17.4 & 8.9 & 21.0 & - & 276 & 254 & 321 & - \\
\hline & $\mathrm{b}_{3}$ & 16.4 & 8.0 & 23.6 & - & 245 & 294 & 300 & - \\
\hline \multicolumn{2}{|l|}{$\bar{x} \mathrm{a}_{2}$} & 16.9 & 7.3 & 21.4 & 15.23 & 255.0 & 290.3 & 315.7 & 287.0 \\
\hline \multirow{3}{*}{$a_{3}$} & $b_{1}$ & 13.3 & 6.7 & 18.3 & - & 253 & 293 & 340 & - \\
\hline & $\mathrm{b}_{2}$ & 13.8 & 7.6 & 19.6 & - & 263 & 274 & 310 & - \\
\hline & $\mathrm{b}_{3}$ & 17.4 & 8.2 & 20.0 & - & 272 & 304 & 303 & - \\
\hline \multicolumn{2}{|l|}{$\bar{x} \mathrm{a}_{3}$} & 14.8 & 7.5 & 19.3 & 13.87 & 262.7 & 290.3 & 317.7 & 290.2 \\
\hline \multicolumn{2}{|l|}{$\bar{x} b_{1}$} & 14.9 & 5.8 & 19.4 & 13.43 & 257.0 & 302.0 & 330.7 & 296.6 \\
\hline \multicolumn{2}{|l|}{$\bar{x} \mathrm{~b}_{2}$} & 17.5 & 7.3 & 20.4 & 15.07 & 271.3 & 280.3 & 319.7 & 290.5 \\
\hline \multicolumn{2}{|l|}{$\bar{x} \mathrm{~b}_{3}$} & 17.8 & 7.9 & 21.4 & 15.70 & 258.7 & 296.0 & 305.7 & 286.8 \\
\hline \multicolumn{2}{|l|}{$\bar{x} \bar{x}$} & 16.73 & 7.00 & 20.40 & 14.72 & 262.4 & 292.8 & 318.7 & 291.3 \\
\hline
\end{tabular}

Seeding rate: $\mathrm{a}_{1}-0.55, \mathrm{a}_{2}-0.65, \mathrm{a}_{3}-0.75$ million viable seeds per ha; $\mathrm{N}$ fertilization: $\mathrm{b}_{1}-25, \mathrm{~b}_{2}-50, \mathrm{~b}_{3}-75 \mathrm{~kg}$ ha ${ }^{-1} \mathrm{~N}$ 
ity characterized by different weather conditions found also Raza and Jørnsgård (2005) when cultivated white lupin in two different localities in Egypt. The yield of more suitable locality (New Valley) was $2.64 \mathrm{t} \mathrm{ha}^{-1}$, whereas the yield of less suitable one (Ismailia) was $1.09 \mathrm{t} \mathrm{ha}^{-1}$ only. Similarly, Milford et al. (1993) in better growing conditions with warm and dry year in Great Britain and France had seed yield from $4.9 \mathrm{tha}^{-1}$ to 5.2 $\mathrm{t} \mathrm{ha} \mathrm{a}^{-1}$ in comparison to worse growing conditions with cool and wet year with seed yield from $1.5 \mathrm{tha}^{-1}$ to 2.4 $t \mathrm{tha}^{-1}$. Payne et al. (2004) reported the maximum white lupin seed yield of $2.13 \mathrm{t} \mathrm{ha}^{-1}$ in the state of Oregon (Pacific Northwest). Based on the results from the climatic conditions of Great Britain, Shield et al. (1996) concluded that depending on drilling date and seeding rate (14-70 seeds per $\mathrm{m}^{2}$ ), seed yield ranged from 0.3 $\mathrm{t}$ ha $\mathrm{a}^{-1}$ to $4.5 \mathrm{t} \mathrm{ha}^{-1}$. Having cultivated white lupin in the climatic conditions of Coastal Spain, López-Bellido et al. (1994) reported that seed yield of $1.87 \mathrm{t} \mathrm{ha}^{-1}$ drilled in the autumn (October-November) was higher than the yield of $1.18 \mathrm{t} \mathrm{ha}^{-1}$ drilled in the winter (Decem-

T a b 1 e 7

Influence of the treatments on seed yield and yield components evaluated by ANOVA

\begin{tabular}{|c|c|c|}
\hline Source of variation & $\mathrm{df}$ & F-ratio \\
\hline \multicolumn{3}{|c|}{ Seed yield } \\
\hline Trial year & 2 & $5468.41^{++}$ \\
\hline Seeding rate & 2 & $100.08^{++}$ \\
\hline $\mathrm{N}$ fertilization & 2 & $15.94^{++}$ \\
\hline \multicolumn{3}{|c|}{ Plant number per $\mathrm{m}^{2}$} \\
\hline Trial year & 2 & $276.77^{++}$ \\
\hline Seeding rate & 2 & $74.45^{++}$ \\
\hline $\mathrm{N}$ fertilization & 2 & $7.56^{++}$ \\
\hline \multicolumn{3}{|c|}{ Pod number per plant } \\
\hline Trial year & 2 & $1048.66^{++}$ \\
\hline Seeding rate & 2 & $1.91^{\mathrm{ns}}$ \\
\hline $\mathrm{N}$ fertilization & 2 & $29.28^{++}$ \\
\hline \multicolumn{3}{|c|}{ Seed number per plant } \\
\hline Trial year & 2 & $814.47^{++}$ \\
\hline Seeding rate & 2 & $9.08^{+}$ \\
\hline $\mathrm{N}$ fertilization & 2 & $23.89^{+}$ \\
\hline \multicolumn{3}{|c|}{ Thousand seed weight } \\
\hline Trial year & 2 & $136.87^{++}$ \\
\hline Seeding rate & 2 & $4.05^{+}$ \\
\hline $\mathrm{N}$ fertilization & 2 & $4.20^{+}$ \\
\hline
\end{tabular}

ns nonsignificant, ${ }^{+}$significant at $\alpha=0.05$,

${ }^{++}$significant at $\alpha=0.01$
ber-January). Not only early drilling but also sufficient amount of precipitation after drilling is important. In spite of early drilling in 2007 ( $16^{\text {th }}$ March), subsequent lack of precipitation caused the lowest seed yield of $1.02 \mathrm{t} \mathrm{ha}^{-1}$. On the other hand, adequate amount of precipitation after early drilling ( $1^{\text {st }}$ April 2008) caused the highest seed yield of $3.59 \mathrm{t} \mathrm{ha}^{-1}$. We can fully agree with Belej (1989) who claimed that sufficient amount of precipitation after drilling is essential to establish an even stand with an expected plant number.

Not only on seed yield but also on the tested yield components had weather in year the highest influence of all tested factors (Table 7). Average number of plants per $\mathrm{m}^{2}$ of all trial years was 47.0. Based on the different seeding rate and $\mathrm{N}$ fertilization treatments, the number of plants per $\mathrm{m}^{2}$ ranged from 24.1 to 65.0. This plant number was closely connected with weather conditions before drilling and during the emergence stage. The highest average number of 55.5 plants per $\mathrm{m}^{2}$ was found in 2008 and the lowest average number of 35.2 in 2006. The highest average plant number of 52.8 was under the treatment with the highest seeding rate $(0.75$ MVS) with the difference of 10.9 plants in comparison with the treatment of 0.55 MVS (Table 5). In general, plant number is highly affecting by seeding rate but this number is reduced by unfavourable weather conditions during a growing season. ANOVA revealed that all tested factors influenced plant number per $\mathrm{m}^{2}$ highly significantly $(\mathrm{P} \leq 0.01)$ (Table 7). The most important factor was weather in year with $77.0 \%$ influence of all tested factors, followed by seeding rate with $20.7 \%$ influence and $\mathrm{N}$ fertilization with $2.1 \%$ influence only. Our results show that 50-55 plants cultivar Amiga per $\mathrm{m}^{2}$ reduces weed infestation of stand. It is generally known that unfavourable weather conditions during the flowering and pod-formation stages negatively influence flower and subsequently pod numbers. Potential ability to set pods is very high but real number of pods is much less owing to various reasons, mainly unfavourable weather. The average number of pods per plant of all tested factors was 4.53. Due to the different seeding rate and $\mathrm{N}$ fertilization treatments, the average pod number ranged from 1.9 to 7.2 per plant. The highest average pod number was found in 2008 (6.4 pods) with the difference of 3.9 pods in comparison with the lowest average number of pods in 2007 ( 2.5 pods only). The highest average number of 4.75 pods was under the treatment with $75 \mathrm{~kg} \mathrm{ha}^{-1} \mathrm{~N}$ (Table 5). Weather in 
year was highly significant $(\mathrm{P} \leq 0.01)$ factor influencing pod number per plant with the highest influence of $97.0 \%$, followed by $\mathrm{N}$ fertilization - even though highly significant $(\mathrm{P} \leq 0.01)$, but with $2.7 \%$ influence only and seeding rate had nonsignificant $(\mathrm{P}>0.05)$ influence (Table 7). Our results correspond with those of LópezBellido et al. (1994). Seed number per plant was highly significantly $(\mathrm{P} \leq 0.01)$ influenced by weather in year with $96.1 \%$ influence, seeding rate and $\mathrm{N}$ fertilization had significant $(\mathrm{P} \leq 0.05)$ influence (Table 7). The highest average seed number per plant (20.4 seeds) was in 2008 with the difference of 13.4 seeds in comparison with the lowest average seed number per plant in 2007 (7.0 seeds only). The highest average seed number of 15.7 was under the treatment with $75 \mathrm{~kg} \mathrm{ha}^{-1} \mathrm{~N}$ with the difference of 2.3 seeds in comparison with the lowest one of 13.4 under the treatment with $25 \mathrm{~kg} \mathrm{ha}^{-1} \mathrm{~N}$ (Table 6). TSW is a genetically established trait that can be more or less modified by weather conditions during the seed-formation stage. TSW ranged from $244 \mathrm{~g}$ to $340 \mathrm{~g}$ with the average weight of $291.3 \mathrm{~g}$. Weather in year had highly significant $(\mathrm{P} \leq 0.01)$ influence on TSW with as high as $93.3 \%$ influence, followed by significant $(\mathrm{P} \leq 0.05)$ influences of $\mathrm{N}$ fertilization $(2.9 \%)$ and seeding rate $(2.8 \%)$. The highest average TSW of $296.6 \mathrm{~g}$ was under the treatment with the lowest seeding rate ( $0.55 \mathrm{MVS})$. In terms of $\mathrm{N}$ fertilization, the lower the $\mathrm{N}$ dose the higher the TSW (Table 6). On the contrary, Wiatrak et al. (2004) found that the higher the $\mathrm{N}$ dose the higher the TSW.

\section{CONCLUSION}

Based on the trial results in the years of 2006-2008, we can draw the following conclusions:

Seed yield of white lupin ranged from 0.79 to 3.94 $\mathrm{t} \mathrm{ha}^{-1}$ and was highly significantly $(\mathrm{P} \leq 0.01)$ influenced by all tested factors (weather in year, seeding rate and $\mathrm{N}$ fertilization). The following factor influence order was ascertained: weather in year with the influence of $97.8 \%$, seeding rate with the influence of $1.8 \%$ and $\mathrm{N}$ fertilization with the influence of $0.3 \%$ only.

The highest seed yield of $2.21 \mathrm{tha}^{-1}$ was found under the highest seeding rate of $0.75 \mathrm{MVS}$ with the difference of $0.36 \mathrm{t} \mathrm{ha}^{-1}(19.5 \%)$ in comparison with the lowest seeding rate of $0.55 \mathrm{MVS}$ and of $0.15 \mathrm{tha}^{-1}(10.7 \%)$ in comparison with the seeding rate of 0.65 MVS.
Seed yield was also positively influenced by $\mathrm{N}$ fertilization. There was found the difference of $0.13 \mathrm{t} \mathrm{ha}^{-1}$ (6.6\%) in seed yield between the highest dose of $75 \mathrm{~kg}$ $\mathrm{ha}^{-1} \mathrm{~N}\left(2.09 \mathrm{t} \mathrm{ha}^{-1}\right)$ and the lowest dose of $25 \mathrm{~kg} \mathrm{ha}^{-1} \mathrm{~N}$ $\left(1.96 \mathrm{t} \mathrm{ha}^{-1}\right)$.

All tested yield components (plant number per $\mathrm{m}^{2}$, pod number per plant, seed number per plant, TSW) were highly significantly $(\mathrm{P} \leq 0.01)$ influenced by weather in year. Plant number per $\mathrm{m}^{2}$ was also highly significantly $(\mathrm{P} \leq 0.01)$ influenced by all tested factors.

When white lupin is cultivated on heavy gleyey alluvial soil, it is recommended to choose the seeding rate of 0.75 MVS per ha and the beginning of April as the most suitable drilling time as well as the dose of $50 \mathrm{~kg} \mathrm{ha}^{-1} \mathrm{~N}$.

Acknowledgement: This work was supported by the Ministry of Agriculture of the Slovak Republic, Grant No. 2006 UO 27/091 05 01/091 0510.

\section{REFERENCES}

BELEJ, J. 1989. Rastlinná výroba [Crop production]. Bratislava: Príroda, 2. vyd., 1989, 354 p. ISBN 80-07-00203-0.

CIESIOŁKA, D. - MUZQUIZ, M. - BURBANO, C. - PEDROSA, M.M. - WYSOCKI, W. - GULEWICZ, K. 2007. Relationship between nitrogen form and the development and yield of Lupinus albus L. from different countries. In Spanish Journal of Agricultural Research, vol. 5, 2007, no. 2, pp. 226-231.

FECÁK, P. - ŠARIKOVÁ, D. - ČERNÝ, I. 2009. Formovanie úrody sóje fazul'ovej v závislosti od klasického a redukovaného systému obrábania pôdy [Yield formation of soybean as influenced by conventional and reduced tillage]. In Acta fytotechnica et zootechnica, vol. 12, 2009, no. 1, pp. 24-28.

GONZÁLEZ-ANDRÉS, F. - CASQUERO, P.A. - SAN-PEDRO, C. - HERNÁNDEZ-SÁNCHEZ, E. 2007. Diversity in white lupin (Lupinus albus L.) landraces from northwest Iberian plateau. In Genetic Resources and Crop Evolution, vol. 54, 2007, no. 1, pp. 27-44.

KOTOROVÁ, D. - ŠOLTYSOVÁ, B. - MATI, R. 2010. Vlastnosti fluvizemí na Východoslovenskej nižine pri ich rozdielnom obrábaní. [Properties of Fluvisols on the East Slovak Lowland under different tillage]. Piešt'any: CVRV - Výskumný ústav agroekológie Michalovce, 1. vyd., 2010. ISBN 978-80-89417-25-4, $160 \mathrm{p}$.

KOŽNAROVÁ, V. - KLABZUBA, J. 2002. Doporučení WMO pro popis meteorologických, resp. klimatologických podmínek definovaného období [Recommendation of World Meteorological Organization to describing meteorological or climatological conditions]. In Rostlinná výroba, vol. 48, 2002, no. 4, pp. 190-192.

LÓPEZ-BELlido, L. - FUENTES, M. - LHAMBY, J.C.B. 
- CASTILLO, J.E. 1994. Growth and yield of white lupin (Lupinus albus) under Mediterranean conditions: effect of sowing date. In Field Crops Research, vol. 36, 1994, no. 2, pp. 87-94.

MILFORD, G.F.J. - DAY, J.M. - LEACH, J.E. - STEVENSON, H.J. - HUYGHE, C. - PAPINEAU, J. 1993. The effect of modifying plant structure on the yield and maturity of the white lupin Lupinus albus. In Annals of Applied Biology, vol. 122, 1993, no. 1, pp. 113-122.

PAYNE, W.A. - CHEN, C. - BALL, D.A. 2004. Agronomic potential of narrow-leafed and white lupins in the Inland Pacific Northwest. In Agronomy Journal, vol. 96, 2004, no. 6, pp. 1501-1508.

RAZA, S. - JØRNSGÅRD, B. 2005. Screening of white lupin accessions for morphological and yield traits. In African Crop Science Journal, vol. 13, 2005, no. 2, pp. 135-141.
SHIELD, I. - STEVENSON, H.J. - LEACH, J.E. - SCOTT, T. - DAY, J.M. - MILFORD, G.F.J. 1996. Effects of sowing date and planting density on the structure and yield of autumn-sown, florally determinate white lupins (Lupinus albus) United Kingdom. In The Journal of Agricultural Science, vol. 127, 1996, no. 2, 183-191.

ŠARIKOVÁ, D. - HNÁT, A. 2005. Úroda hrachu siateho pri konvenčnej agrotechnike a pri sejbe do nespracovanej pôdy [Yield of pea cultivated under conventional tillage and no-tillage]. In Agriculture (Pol'nohospodárstvo), vol. 51, 2005, no. 5, pp. 267-273.

WIATRAK, P.J. - WRIGHT, D.L. - MAROIS, J.J. 2004. Influence of residual nitrogen and tillage on white lupin. In Agronomy Journal, vol. 96, 2004, no. 6, pp. 1765-1770.

Received: November, $8^{\text {th }}, 2010$ 